\title{
PENGELOMPOKAN SAYURAN BERDASARKAN KEMIRIPAN KANDUNGAN GIZI
}

\author{
Ayu Sandra Tiara Dewi ${ }^{1 \S}$, Ni Luh Putu Suciptawati ${ }^{2}$, I Gusti Ayu Made Srinadi ${ }^{3}$ \\ ${ }^{1}$ Jurusan Matematika, Fakultas MIPA - Universitas Udayana [Email: ayusandra0607@gmail.com] \\ ${ }^{2}$ Jurusan Matematika, Fakultas MIPA - Universitas Udayana [Email: suciptawati@unud.ac.id] \\ ${ }^{3}$ Jurusan Matematika, Fakultas MIPA - Universitas Udayana [Email: srinadi@unud.ac.id] \\ ${ }^{\S}$ Corresponding Author
}

\begin{abstract}
One of the either of health maintain is trough the food consumption pattern that fulfill nutrient content. Vegetables are needed to body as source of vitamin, mineral and fiber in gaining healthy food pattern as a recommended guidance of nutrient balancing for optimal health. This research is aimed to determine several type of vegetables that have similarity of nutrient content and types of nutrient content which characterized of each vegetables grup. The method is biplot analysis. Biplot analysis can show the type of vegetables and type of nutrient content simultaneously in a twodimensional plot. From this plot, the information about vegetables that have similarity of nutrient content and type of nutrient content which characterized of each vegetables group. This research used 37 type of vegetable as an observation object and type of nutrient content observed is 13 . The result of this analysis is obtained 7 vegetables group with different characteristic changes.
\end{abstract}

Keywords: Biplot, Similarity, Vegetables, Type of Nutrient Content

\section{PENDAHULUAN}

Salah satu upaya dalam menjaga kesehatan adalah melalui pola konsumsi makanan yang memenuhi kandungan gizi. Semua orang memerlukan kandungan gizi yang terkandung dalam berbagai macam olahan sayur. Hampir seluruh penduduk Indonesia (97,29 persen) mengkonsumsi sayur (BPS, 2016). Sayur diperlukan tubuh sebagai sumber vitamin, mineral dan serat dalam mencapai pola makan sehat sesuai anjuran pedoman gizi seimbang untuk kesehatan yang optimal. Sebagian vitamin dan mineral yang terdapat dalam sayur mempunyai fungsi sebagai antioksidan sehingga dapat mengurangi kejadian penyakit tidak menular terkait gizi, sebagai dampak dari kelebihan atau kekurangan gizi (Kementrian Kesehatan RI, 2014).

Mengingat jumlah sayuran ada berbagai jenis dan nilai kandungan gizi yang bervariasi serta ada beberapa sayuran yang memiliki kandungan gizi sama dengan sayuran lain, maka dipandang perlu untuk melakukan suatu analisis statistika berupa analisis biplot. Berbagai jenis sayuran menggunakan analisis biplot akan dikelompokkan menjadi beberapa kelompok setelah itu mencari penciri dari masing- masing kelompok.

Tujuan dari penelitian ini adalah dapat diperoleh tambahan informasi tentang macammacam sayuran beserta kandungan gizinya, baik itu tentang beberapa sayuran yang memiliki kemiripan kandungan gizi maupun jenis kandungan gizi yang menjadi penciri dari masing-masing kelompok sayuran.

Menurut Jollife (2002) analisis biplot adalah salah satu teknik peubah ganda yang menyajikan $\mathrm{n}$ pengamatan dan $\mathrm{p}$ peubah secara bersamaan dalam bidang dua dimensi. Biplot adalah salah satu upaya menggambarkan data yang ada pada tabel dalam grafik berdimensi dua.

Analisis biplot berguna untuk memperoleh kedekatan antar objek, gambaran tentang suatu peubah, baik tentang keragamannya maupun korelasinya, serta keterkaitan antara objek-objek 
melalui peragaan grafik (Mattjik \& Sumertajaya, 2011).

\section{Ulasan Pustaka}

\subsection{Analisis Biplot}

Analisis biplot merupakan salah satu teknik peubah ganda yang menyajikan plot pengamatan $n$ dan peubah $p$ secara bersamaan dalam bidang dua dimensi (Jollife, I. 2002).

Penyajian plot pengamatan $\mathrm{n}$ dan peubah $\mathrm{p}$ secara bersamaan dapat memberikan tambahan informasi yang lebih baik tentang hubungan antara peubah dan pengamatan. Empat hal penting yang bisa didapatkan dari tampilan biplot adalah (Mattjik, A.A. dan Sumertajaya, I M., 2011):

a) Kedekatan antar objek yang diamati.

Kedekatan antarobjek diinterpretasikan sebagai kemiripan sifat dua objek. Semakin dekat letak dua objek maka kemiripan sifat dua objek tersebut semakin tinggi.

b) Keragaman peubah.

Keragaman peubah bisa dilihat dari panjang vektor peubah. Peubah dengan nilai keragaman kecil akan digambarkan sebagai vektor pendek sedangkan peubah dengan nilai keragaman yang tinggi akan digambarkan sebagai vektor panjang.

c) Korelasi antarpeubah.

Dua peubah dikatakan memiliki korelasi positif apabila digambarkan sebagai dua buah vektor yang membentuk sudut lancip. Dua peubah dikatakan memiliki korelasi negatif apabila digambarkan sebagai dua buah vektor yang membentuk sudut tumpul. Sedangkan dua peubah dikatakan tidak memiliki korelasi apabila digambarkan sebagai dua buah vektor yang membentuk sudut siku-siku.

d) Nilai peubah pada suatu objek.

Objek yang terletak searah dengan arah dari vektor peubah, memiliki nilai di atas ratarata. Sebaliknya, objek yang terletak berlawanan dengan arah vektor peubah, memiliki nilai di bawah rata-rata. Nilai peubah pada suatu objek digunakan untuk melihat peubah penciri dari setiap objek. Nilai peubah pada suatu objek dapat dilihat dengan melakukan proyeksi ortogonal dari objek ke vektor peubah.

\subsubsection{Penguraian Nilai Singular}

Analisis biplot merupakan gambaran dua dimensi dari suatu matriks data $\mathrm{X}$ yang menampilkan titik untuk masing-masing vektor pengamatan $n$ objek bersama dengan titik untuk masing-masing $\mathrm{p}$ peubah. Jadi dari suatu matriks data $X$, dengan masing-masing baris mewakili objek penelitian dan masingmasing kolom mewakili suatu peubah. matriks $X$ memuat peubah-peubah yang akan diteliti sebanyak $p$ dan objek penelitian sebanyak $n$. Analisis biplot didasarkan pada penguraian nilai singular. Definisi dari penguraian nilai singular adalah suatu matriks ${ }_{n} X_{p}$ yang dapat diuraikan menjadi:

$$
{ }_{n} X_{p}={ }_{n} U_{r} L_{r} A_{p}^{\prime}
$$

Keterangan :

1. $U$ dan $A$ merupakan matrik dengan kolom ortonormal $\left(U^{\prime} U=A^{\prime} A=I r\right)$.

$\mathrm{A}_{\mathrm{pxr}}=\left[\mathrm{a}_{1}, \mathrm{a}_{2}, \ldots \mathrm{a}_{\mathrm{r}}\right]$ merupakan vektor ciri dari $X^{\prime} X$ dan

$\mathrm{U}_{\mathrm{nxr}}=\left[\frac{\mathrm{X}_{\mathrm{a}_{1}}}{\sqrt{\lambda_{1}}}, \frac{\mathrm{X}_{\mathrm{a}_{2}}}{\sqrt{\lambda_{2}}}, \ldots \frac{\mathrm{X}_{\mathrm{ar}_{\mathrm{r}}}}{\sqrt{\lambda_{\mathrm{r}}}}\right]$, dengan

$\lambda_{1}, \lambda_{2}, \ldots, \lambda_{\mathrm{r}}$ merupakan akar ciri tidak nol dari $X^{\prime} X$.

2. $L$ merupakan matrik diagonal berukuran $r x r$ dengan unsur diagonalnya

$\sqrt{\lambda_{1}}>\sqrt{\lambda_{2}}>\cdots>\sqrt{\lambda_{\mathrm{r}}}$. Unsur - unsur diagonal ini disebut nilai singular matriks $X$.

$$
{ }_{\mathrm{r}} L_{r}=\left[\begin{array}{cccc}
\sqrt{\lambda_{1}} & 0 & \cdots & 0 \\
0 & \sqrt{\lambda_{2}} & \cdots & 0 \\
\vdots & \vdots & \ddots & \vdots \\
0 & 0 & \cdots & \sqrt{\lambda_{r}}
\end{array}\right]
$$

3. Kolom-kolom matriks A adalah vektor ciri dari matriks $X^{\prime} X$.

4. $r$ adalah pangkat matriks $X, r \leq \min (n, p)$.

Kemudian dapat didefinisikan $L^{\alpha}$ untuk $0 \leq$ $\alpha \leq 1$ merupakan matriks diagonal yang berukuran $r \times r$ dengan unsur - unsur diagonalnya $\quad \sqrt{\lambda_{1^{\alpha}}} \geq \sqrt{\lambda_{2^{\alpha}}} \geq \cdots \geq \sqrt{\lambda_{\mathrm{r}^{\alpha}}}$, dan definisi ini berlaku juga untuk $\mathrm{L}^{1-\mathrm{a}}$ dengan unsur - unsur diagonalnya adalah $\sqrt{\lambda_{1^{1-\alpha}}} \geq$ $\sqrt{\lambda_{2^{1-\alpha}}} \geq \cdots \geq \sqrt{\lambda_{\mathrm{r}^{1-\alpha}}} . \quad$ Menurut Jollife 
(2002) , misalkan $\mathrm{G}=\mathrm{UL}^{\alpha}$ dan $\mathrm{H}^{\prime}=\mathrm{L}^{1-\alpha} \mathrm{A}^{\prime}$ dengan $\alpha$ besarnya $0 \leq \alpha \leq 1$. Persamaan (1) menjadi

$$
\mathrm{X}=\mathrm{U} \mathrm{L}^{\mathrm{a}} \mathrm{L}^{1-\alpha} \mathrm{A}^{\prime}=\mathrm{GH}^{\prime}
$$

Menurut Jollife (2002) untuk mendeskripsikan biplot perlu mengambil nilai $\alpha$ dalam mendefinisikan $\mathrm{G}$ dan $\mathrm{H}$. Pemilihan nilai $\alpha$ pada $G=U L^{\alpha}$ dan $H^{\prime}=\mathrm{L}^{1-\alpha} A^{\prime}$ bersifat sembarang dengan syarat $0 \leq \alpha \leq 1$. Pengambilan nilai ekstrim $\alpha=0$ dan $\alpha=1$ berguna dalam interpretasi biplot.

1. $\alpha=0$

Jika $\alpha=0$, maka $G=U$ dan $H^{\prime}=L A^{\prime}$. Berarti bahwa secara keseluruhan pemilihan $\alpha=0$ akan memberikan kesesuaian untuk data dan keragaman. Tampilan biplot akan lebih mampu menggambarkan keragaman peubah, hubungan antar peubah sekaligus mendapatkan informasi mengenai pola objek.

2. $\alpha=1$

Jika $\alpha=1$, maka $G=U L$ dan $H^{\prime}=A^{\prime}$. Berarti bahwa secara keseluruhan pemilihan $\alpha=1$ akan memberikan kesesuaian untuk data dan bentuk. Tampilan biplot akan lebih memberikan gambaran jarak antara pasangan baris sehingga baik digunakan untuk melihat kedekatan objek-objek.

\section{METODE PENELITIAN}

Data yang digunakan dalam penelitian ini adalah data sekunder yang diambil dari United States Departement of Agriculture America. Peneliti menggunakan 37 jenis sayuran sebagai objek amatan dengan 13 jenis kandungan gizi sebagai peubah. Langkah analisis data yang harus dilakukan dalam penelitian ini adalah :

1. Penyiapan Data

Peubah yang digunakan pada penelitian ini ada 13 dan satuan pengamatan untuk peubah tidak sama sehingga sebelum melakukan analisis, data perlu distandarisasi.

2. Menganalisis Data dengan Analisis Biplot

a. Pemilihan Parameter

b. Penguraian Nilai Singular
Melalui penguraian nilai singular maka akan diperoleh:

- Vektor-vektor eigen ;

- Nilai-nilai eigen;

- Koordinat-koordinat dimensi peragaman biplot.

c. Pembuatan Plot

3. Interpretasi Hasil.

Hasil akhir dari analisis biplot adalah dapat ditentukan penciri masing - masing gizi pada sayuran.

\section{HASIL DAN PEMBAHASAN}

\section{Pengelompokan Sayuran}

Singular Value Decomposition (SVD) dilakukan untuk menguraikan matriks $\mathrm{X}$ menjadi $U L A^{\prime}$. Matriks $U$ adalah matriks dengan kolom ortonormal berukuran $37 \times 13$. Matriks $L$ merupakan matriks diagonal berukuran $13 \times 13$ yang memuat akar dari nilai eigen matriks $X^{\prime} X$ dengan $r$ merupakan rank dari matriks $X$. Matriks $A$ adalah matriks orthonormal berukuran $13 \times 13$ yang memuat vektor eigen dari $X^{\prime} X$ dengan $p$ merupakan banyaknya kolom dari matriks $X$.

Tabel 1. Nilai Eigen Matriks $X^{\prime} X$

\begin{tabular}{|c|c|}
\hline Nilai Eigen & Persentase Kumulatif Nilai Eigen \\
\hline 7,182068654 & 0,55246682 \\
\hline 1,932339304 & 0,701108304 \\
\hline 1,222539871 & 0,795149833 \\
\hline 0,795957001 & 0,856377295 \\
\hline 0,690175115 & 0,909467688 \\
\hline 0,488437916 & 0,947039835 \\
\hline 0,402186551 & 0,977977262 \\
\hline 0,109752942 & 0,986419796 \\
\hline 0,06505136 & 0,991423747 \\
\hline 0,048750136 & 0,995173758 \\
\hline 0,036304814 & 0,997966436 \\
\hline 0,020120086 & 0,999514135 \\
\hline 0,00631625 & 1 \\
\hline
\end{tabular}

Presentase kumulatif dari nilai eigen tersebut menyatakan seberapa besar kemampuan biplot dapat menjelaskan data. Berdasarkan hasil dari presentase kumulatif nilai eigen yang 
ditampilkan dalam Tabel 1 analisis biplot dapat menjelaskan $70,11 \%$ dari keseluruhan data dalam dimensi dua. Penggambaran biplot pada penelitian ini dilihat dari 2 komponen utama pertama, yaitu membuat plot antara komponen 1 dengan komponen 2 dengan presentase nilai eigen kumulatif sebesar 70,11\%.

Berdasarkan persamaan pada $X=U L^{\alpha} L^{1-\alpha} A^{\prime}$, jika dimisalkan $G=U L^{\alpha}$ dan $H^{\prime}=L^{1-\alpha} A^{\prime}$, maka ketika nilai $\alpha=0$ akan diperoleh $G=U$ dan $H^{\prime}=L A^{\prime}$. Matriks $\mathrm{G}$ dan matriks $H$ mempunyai peranan yang penting dalam biplot, karena dua matriks inilah yang akan menentukan gambaran titik-titik objek dan vektor peubah dalam biplot. Matriks G merupakan matriks yang terdiri dari skor komponen utama dari nilai amatan yang menentukan koordinat titik objek, sedangkan matriks $\mathrm{H}$ merupakan matriks yang terdiri dari vektor eigen dari nilai amatan yang menentukan koordinat vektor peubah.

Oleh karena biplot ditampilkan dalam bidang berdimensi dua maka hanya diambil dua komponen utama dari data pada matriks $G$ dan dua komponen utama pada matriks $H^{\prime}$. Pada penggambaran plot antara komponen 1 dengan komponen 2, komponen 1 akan menjadi sumbu$X$ sedangkan komponen 2 menjadi sumbu- $Y$. Setelah diperoleh matriks maka dapat dibentuk plot dari koordinat masing-masing matriks yang dapat dilihat pada gambar berikut:

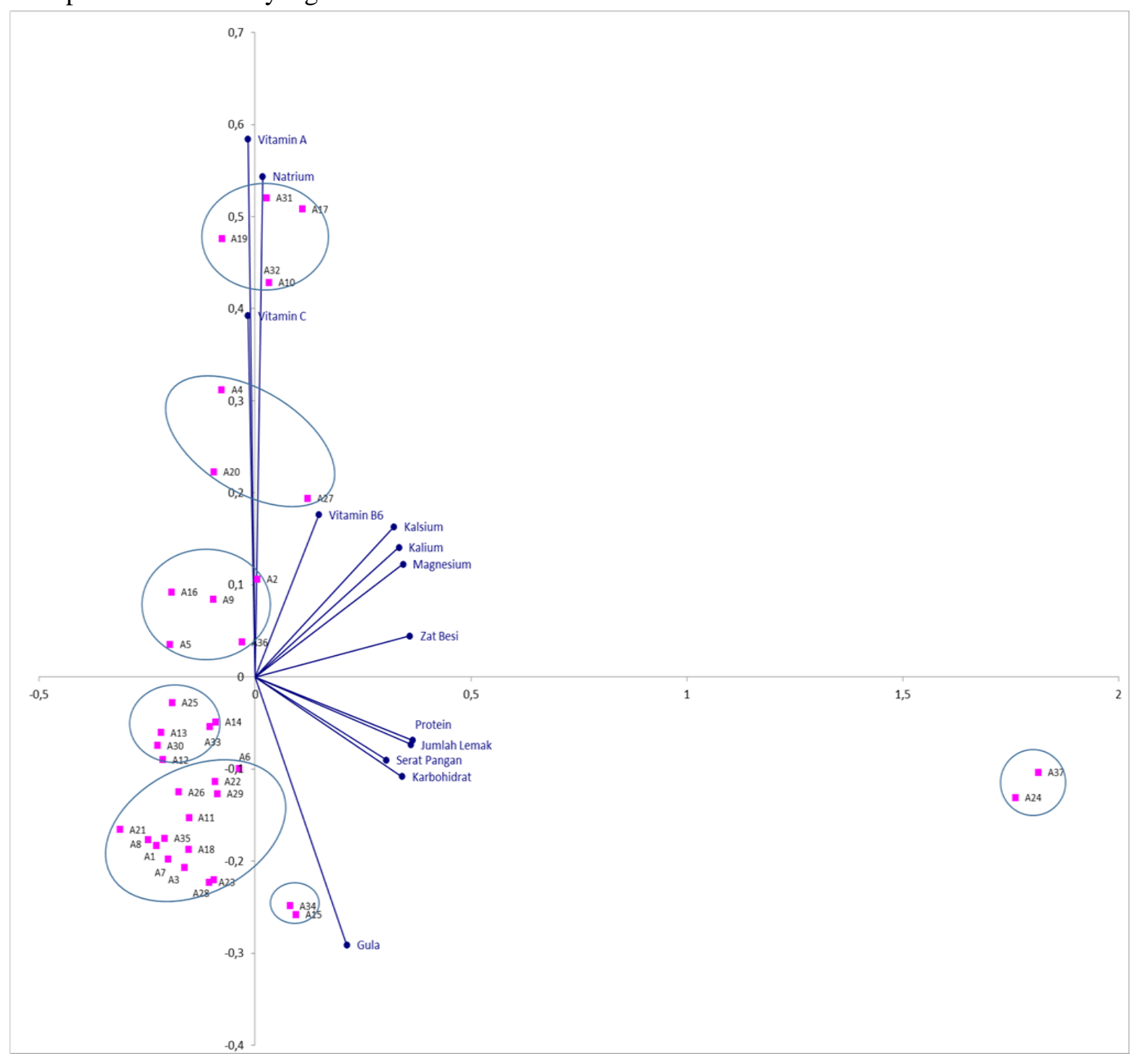

Gambar 1. Pengelompokan Sayuran dalam Biplot 
Berdasarkan pengelompokkan yang ditampilkan dalam gambar 1 terdapat 5 kelompok yang terbentuk, kelompok 1 yang terdiri dari peterseli, kangkung, kale, horenso, bayam. Kelompok 2 yang terdiri dari wortel, sawi, pare. Kelompok 3 yang terdiri dari artichoke, seledri, brokoli, selada, kubis brussel. Kelompok 4 yang terdiri dari lobak, labu siam, kembang kol, jamur, endive, kohlrabi. Kelompok 5 yang terdiri dari taoge, asparagus, kentang, tomat, mentimun, kubis, terung, sawi putih, bendi, buncis, kacang panjang, rebung, daun bawang, kecambah alfalfa. Kelompok 6 yang terdiri dari kacang polong dan ercis. Kelompok 7 yang terdiri dari kecipir dan kedelai.

Setelah terbentuknya kelompok-kelompok sayuran, maka akan dilihat vektor jenis kandungan gizi mana yang memberikan sumbangan keragaman yang relatif besar terhadap masing-masing kelompok sayuran yang selanjutnya disebut sebagai peubah penciri dari masing-masing kelompok sayuran tersebut. Untuk itu akan dilakukan plot ulang hasil pengelompokan sayuran tadi, di mana data yang digunakan merupakan data nilai rata-rata dari setiap jenis kandungan gizi yang dimiliki masing-masing kelompok sayuran.

Singular Value Decomposition (SVD) dilakukan untuk menguraikan matriks $X$ menjadi $=U L A^{\prime}$. Matriks $U$ adalah matriks dengan kolom ortonormal berukuran $7 \times 7$. Matriks $L$ merupakan matriks diagonal berukuran $7 \times 7$ yang memuat akar dari nilai eigen matriks $X^{\prime} X$ dengan $r$ merupakan rank dari matriks $X$. Matriks $A$ adalah matriks orthonormal berukuran $13 \times 7$ yang memuat vektor eigen dari $X^{\prime} X$ dengan $p$ merupakan banyaknya kolom dari matriks $X$.

Presentase kumulatif dari nilai eigen tersebut menyatakan seberapa besar kemampuan biplot dapat menjelaskan data. Berdasarkan hasil dari presentase kumulatif nilai eigen yang ditampilkan dalam Tabel 2 analisis biplot dapat menjelaskan $91,11 \%$ dari keseluruhan data dalam dimensi dua. Penggambaran biplot pada penelitian ini dilihat dari 2 komponen utama pertama, yaitu membuat plot antara komponen 1 dengan komponen 2 dengan presentase nilai eigen kumulatif sebesar $91,11 \%$.

Tabel 2. Nilai Eigen Matriks $X^{\prime} X$

\begin{tabular}{|c|c|}
\hline Nilai Eigen & Persentase Kumulatif Nilai Eigen \\
\hline 9,355020441 & 0,719616957 \\
\hline 2,490294973 & 0,911178109 \\
\hline 0,626123399 & 0,959341447 \\
\hline 0,411658064 & 0,991007452 \\
\hline 0,106628134 & 0,999209616 \\
\hline 0,01027499 & 1 \\
\hline 0,000002116 & 1 \\
\hline
\end{tabular}

Berdasarkan persamaan pada $\quad X=$ $U L^{\alpha} L^{1-\alpha} A^{\prime}$, jika dimisalkan $G=U L^{\alpha}$ dan $H^{\prime}=L^{1-\alpha} A^{\prime}$, maka ketika nilai $\alpha=0$ akan diperoleh $G=U$ dan $H^{\prime}=L A^{\prime}$. Matriks $G$ dan matriks $H$ mempunyai peranan yang penting dalam biplot, karena dua matriks inilah yang akan menentukan gambaran titik-titik objek dan vektor peubah dalam biplot. Matriks $G$ merupakan matriks yang terdiri dari skor komponen utama dari nilai amatan yang menentukan koordinat titik objek, sedangkan matriks $\mathrm{H}$ merupakan matriks yang terdiri dari vektor eigen dari nilai amatan yang menentukan koordinat vektor peubah.

Oleh karena biplot ditampilkan dalam bidang berdimensi dua maka hanya diambil dua komponen utama dari data pada matriks $G$ dan dua komponen utama pada matriks $H^{\prime}$. Pada penggambaran plot antara komponen 1 dengan komponen 2, komponen 1 akan menjadi sumbu$X$ sedangkan komponen 2 menjadi sumbu- $Y$. Setelah diperoleh matriks maka dapat dibentuk plot dari koordinat masing-masing matriks yang dapat dilihat pada gambar 2 sebagai berikut. 


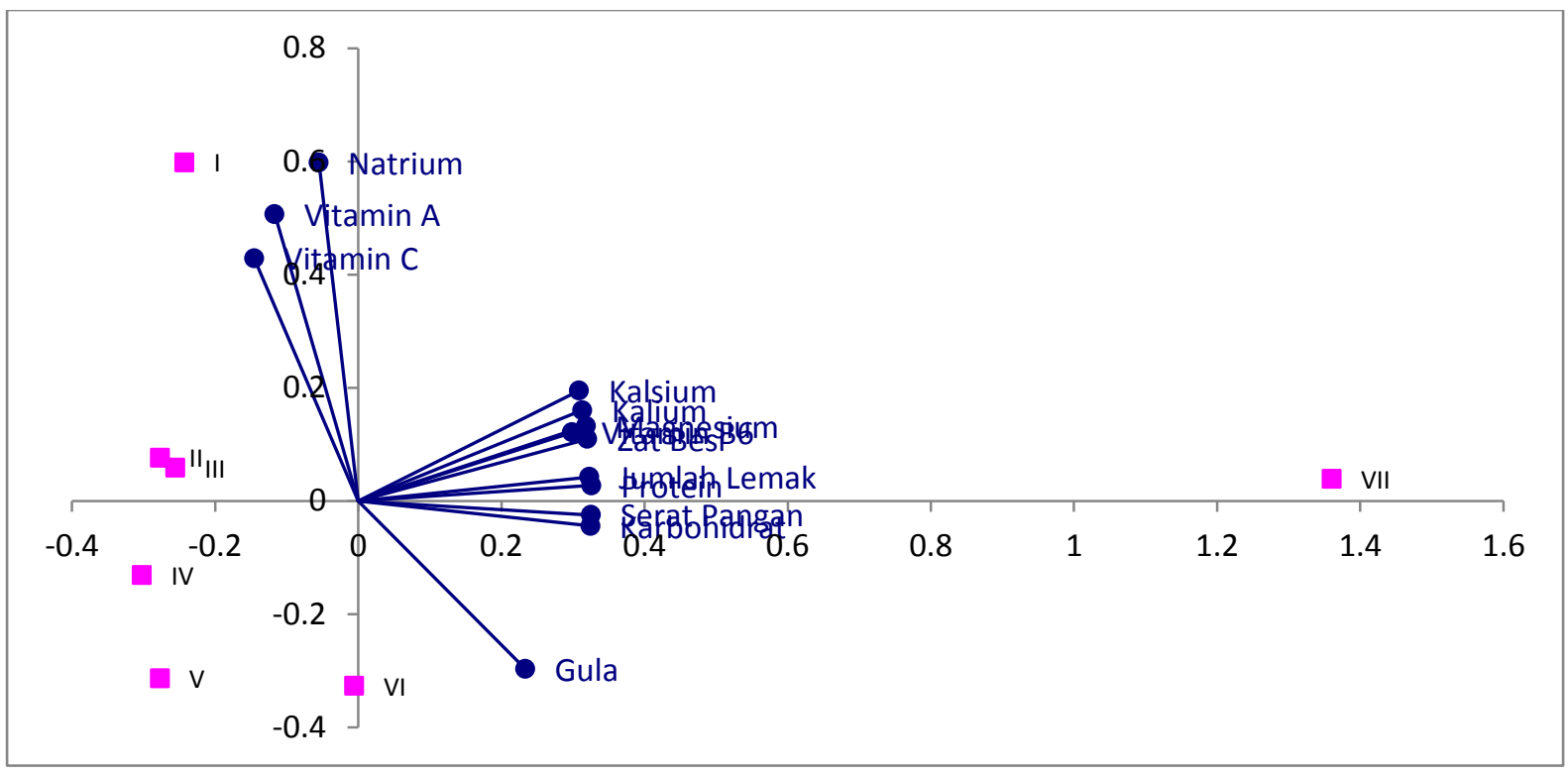

Gambar 2. Plot dengan Kelompok Sebagai Objek

Pada Gambar 2 menunjukkan hasil kelompok mi instan maka perlu dilakukan penggambaran biplot yang menampilkan titik proyeksi ortogonal dari masing-masing untuk setiap kelompok sayuran dan vektor jenis kandungan gizi.

Untuk mengetahui jenis kandungan gizi kelompok sayuran terhadap setiap vektor jenis kandungan gizi. Setelah melakukan proyeksi orthogonal dapat diperoleh pengelompokan yang menjadi penciri dari masing-masing sebagai berikut :

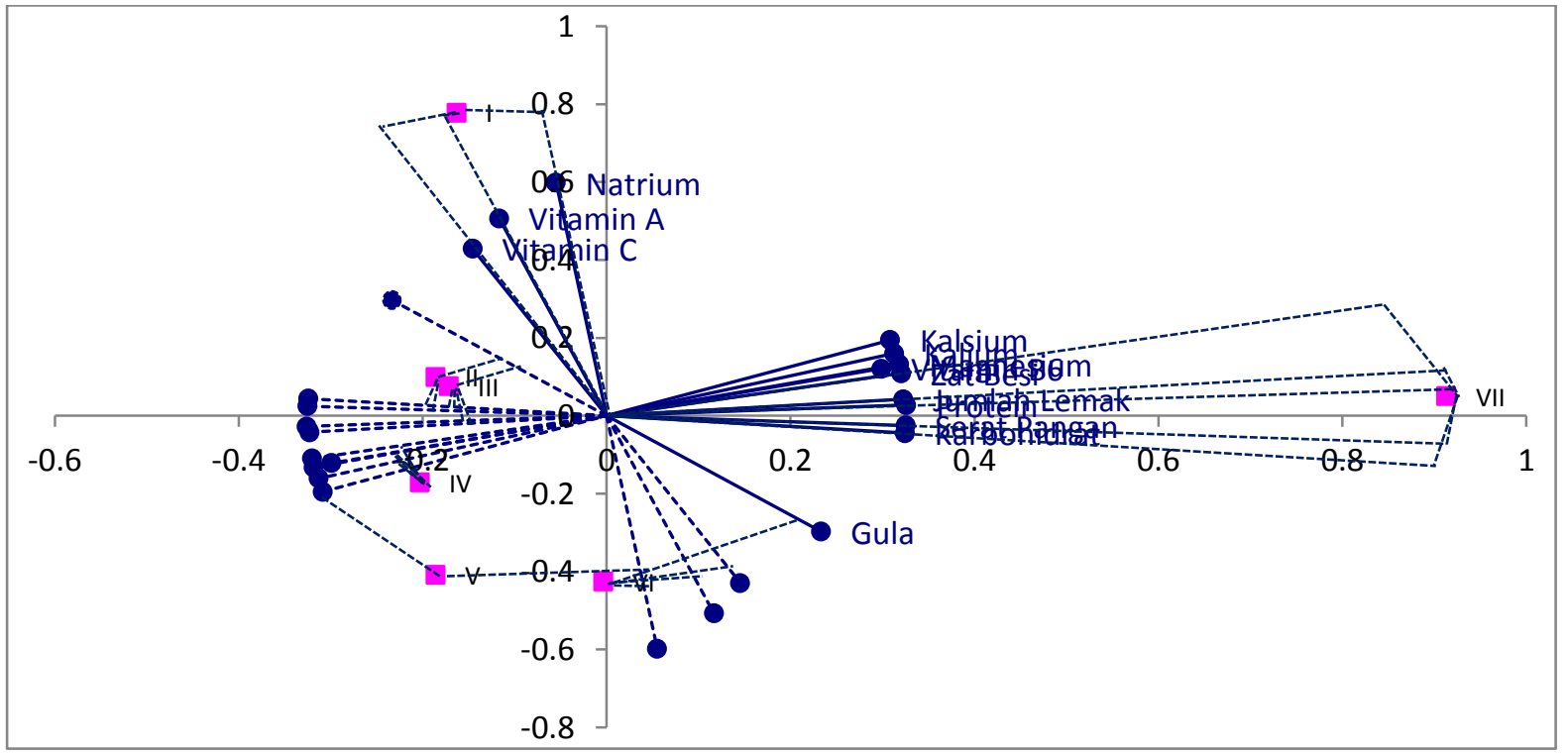

Gambar 3. Proyeksi Orthogonal Objek Terhadap Peubah

Pada Gambar 3 berikut menampilkan hasil proyeksi ortogonal dari setiap kelompok sayuran terhadap vektor jenis kandungan gizi yang menjadi pencirinya. Semakin jauh dari titik asal sebuah proyeksi dari objek jatuh pada vektor peubah, maka semakin besar nilai objek pada peubah tersebut. Sebaliknya, semakin dekat dengan titik asal sebuah proyeksi dari objek jatuh pada vektor peubah, maka semakin kecil nilai objek pada peubah tersebut.

Hasil proyeksi otogonal yang ditunjukan pada Gambar 3, menunjukan jenis kandungan gizi yang menjadi penciri dari masing-masing kelompok mi, dan terangkum dalam Tabel 3. 
Tabel 3. Jenis Kandungan Gizi Penciri Kelompok Sayuran

\begin{tabular}{|c|c|c|c|c|}
\hline Nama Kelompok & \multicolumn{2}{|c|}{ Jenis Sayuran } & Penciri & Keterangan Gambar \\
\hline \multirow{3}{*}{ Kelompok 1} & Bayam & Kale & \multirow{3}{*}{ Vitamin A, Natrium, dan Vitamin C } & \\
\hline & Peterseli & Horenso & & \\
\hline & Kangkung & & & \\
\hline \multirow{3}{*}{ Kelompok 2} & Wortel & & \multirow{3}{*}{ Vitamin B6, Vitamin A, dan Natrium } & \\
\hline & Sawi & & & \\
\hline & Pare & & & \\
\hline \multirow{3}{*}{ Kelompok 3} & Artichoke & Selada & \multirow{3}{*}{ Natrium, Vitamin C, dan Vitamin A } & \\
\hline & Seledri & Kubis Brussel & & \\
\hline & Brokoli & & & \\
\hline \multirow{3}{*}{ Kelompok 4} & Lobak & Jamur & \multirow{3}{*}{ Vitamin C, Serat Pangan, dan Natrium } & \\
\hline & Labu Siam & Endive & & \\
\hline & Kembang Kol & Kohlrabi & & \\
\hline \multirow{7}{*}{ Kelompok 5} & Taoge & Sawi Putih & \multirow{7}{*}{ Vitamin B6, Gula, dan Karbohidrat } & \\
\hline & Asparagus & Bendi & & \\
\hline & Kentang & Buncis & & 4 \\
\hline & Tomat & Kacang Panjang & & 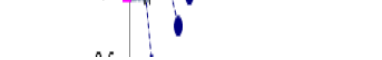 \\
\hline & Mentimun & Rebung & & \\
\hline & Kubis & Daun Bawang & & \\
\hline & Terung & Kecambah Alfalfa & & \\
\hline \multirow{2}{*}{ Kelompok 6} & \multicolumn{2}{|l|}{ Kacang Polong } & \multirow{2}{*}{ Gula dan Karbohidrat } & \\
\hline & Ercis & & & \\
\hline \multirow{2}{*}{ Kelompok 7} & Kecipir & & \multirow{2}{*}{\multicolumn{2}{|c|}{ Jumlah Lemak, Protein, dan Zat Besi }} \\
\hline & Kedelai & & & \\
\hline
\end{tabular}

Berdasarkan Tabel 3 dapat dilihat bahwa ketujuh kelompok diatas memiliki pencirinya masing-masing yang mewakili kandungan gizi tertinggi pada setiap kelompoknya menurut United States Departement of Agriculture America.

\section{SIMPULAN DAN SARAN}

Berdasarkan pada pembahasan yang dipaparkan pada bab pembahasan, maka dapat disimpulkan beberapa hal berdasarkan rumusan masalah, yaitu:

Hasil yang didapat dari analisis data terbentuk tujuh kelompok jenis sayuran. Masing-masing kelompok memiliki peubah penciri masing-masing. Ketujuh kelompok sayuran tersebut antara lain sebagai berikut.

a. Kelompok 1, yaitu peterseli, kangkung, kale, horenso, bayam.
Jenis kandungan gizi yang menjadi penciri dari jenis sayuran pada kelompok 1, yaitu vitamin A, natrium, dan vitamin $\mathrm{C}$.

b. Kelompok 2, yaitu wortel, sawi, pare.

Jenis kandungan gizi yang menjadi penciri dari jenis sayuran pada kelompok 2, yaitu vitamin B6, vitamin A, dan natrium.

c. Kelompok 3, yaitu artichoke, seledri, brokoli, selada, kubis brussel.

Jenis kandungan gizi yang menjadi penciri dari jenis sayuran pada kelompok 3, yaitu natrium, vitamin $\mathrm{C}$, dan vitamin $\mathrm{A}$.

d. Kelompok 4, yaitu lobak, labu siam, kembang kol, jamur, endive, kohlrabi.

Jenis kandungan gizi yang menjadi penciri dari jenis sayuran pada kelompok 4, yaitu vitamin $\mathrm{C}$, serat pangan, natrium.

e. Kelompok 5, yaitu taoge, asparagus, kentang, tomat, mentimun, kubis, terung, sawi putih, 
bendi, buncis, kacang panjang, rebung, daun bawang, kecambah alfalfa.

Jenis kandungan gizi yang menjadi penciri dari jenis sayuran pada kelompok 5, yaitu vitamin B6, gula, dan karbohidrat.

f. Kelompok 6, yaitu kacang polong dan ercis. Jenis kandungan gizi yang menjadi penciri dari jenis sayuran pada kelompok 6 , yaitu gula dan karbohidrat.

g. Kelompok 7, yaitu kecipir dan kedelai Jenis kandungan gizi yang menjadi penciri dari jenis sayuran pada kelompok 7 , yaitu jumlah lemak, protein, zat besi.

Dari ketujuh kelompok masing-masing memiliki kandungan gizi yang sangat bermanfaat bagi tubuh. Jika ingin memenuhi kebutuhan gizi harian tetapi tidak menemukan sayur tersebut masih ada sayuran lain yang memiliki kandungan gizi sama dan dapat menggantikannya.

\section{DAFTAR PUSTAKA}

BPS, 2016. Konsumsi Buah Dan Sayur Susenas Maret 2016, : BPS Provinsi Bali.

Johnson, R.A and Dean W. Wichern. 1998. Applied Multivariate Statistical Analysis. Prentice Hall International Inc.New Jersey.

Jollife, I., 2002. Principal Component Analysis. New York: Springer-verlag.

Kementrian Kesehatan RI, 2014. Pedoman Gizi Seimbang, Jakarta: Kementrian Kesehatan Ri.

Mattjik, A. A. \& Sumertajaya, I. M., 2011. Sidik Peubah Ganda. 1st ed.:IPB PRESS.

United States Department of Agriculture (USDA). National Nutrient Database for Standard Reference, 2017. Available:

http://www.nal.usda.gov/fnic/foodcomp/c gi-bin/list nut edit.pl/, accessed on 1 Agustus 2017. 